\title{
Quality Characteristics of Gamma Irradiated Beefburger Formulated with Partial Replacement of Beef Fat with Olive Oil and Wheat Bran Fibers
}

\author{
Karema A. Mahmoud', Hesham M. Badr ${ }^{2, *}$ \\ ${ }^{1}$ Atomic Energy Authority, National Center for Radiation Research and Technology, Cairo, Egypt; ${ }^{2}$ Atomic Energy Authority, Nu- \\ clear Research Center, Abou Zaabal, Egypt. \\ Email: *heshambadr_aea@yahoo.co.uk
}

Received January $21^{\text {st }}, 2011$; revised July $15^{\text {th }}, 2011$; accepted July $23^{\text {rd }}, 2011$.

\begin{abstract}
Five beefburger formulations were prepared with substituting beef fat with olive oil and levels of wheat bran and irradiated at doses of 0 and $3 \mathrm{kGy}$, then samples were refrigerated stored and their quality characteristics were investigated. The results indicated that replacement of beef fat with olive oil and ascending levels of wheat bran in burger batter significantly decreased their contents of total lipids and saturated fatty acids, while increased their contents of dietary fibers, unsaturated fatty acids and the ratios of unsaturated and polyunsaturated fatty acids to the saturated ones. Moreover, significant improvements were observed in the cooking yield and moisture and fat retention of samples, proportionally to the added wheat bran, and both raw and cooked burger samples showed a high sensory acceptability. Irradiation of samples effectively inactivated Staphylococcus aureus, Salmonella and enterobacteriaceae and significantly reduced the counts of mesophilic and psychrophilic bacteria as well as molds and yeasts without any adverse effects on the quality characteristics of samples. Thus, reducing beef fat levels with the addition of olive oil and wheat bran produced a highly acceptable beefburger products with improved nutritional content as well as improved cooking and binding properties, while irradiation improved their microbiological quality.
\end{abstract}

Keywords: Irradiation, Beefburger, Low-Fat, Microbiological Quality, Olive Oil, Wheat Bran

\section{Introduction}

Food and its manufacture are currently attracting significant scientific and public interest due to extensive media coverage of diet-related diseases and their influence on the health and wellbeing of communities. Recent advances in food and nutrition sciences have highlighted that it is possible to help optimize certain physiological functions through the diet and/or dietary components in order to improve health status and wellbeing and/or reduce the risk of disease. Like other food-related sectors, the meat industry is undergoing major transformations, driven among other things by changes in consumer demands [1]. Meat and meat products are seen to be a major source of fat in the diet and provide high amounts of saturated fatty acids and cholesterol, which have been implicated in diseases include various cancers, obesity, hypertension, cardiovascular diseases, and coronary heart diseases [2-5]. A focus of dietary recommendations for cardiovascular disease prevention and treatment has been a reduction of saturated fat intake [6].

However, Fats in meat products play important role in stabilizing meat emulsions, reducing cooking loss, improving water holding capacity, providing juiciness and hardness and have considerable effects on the binding, rheological and structural properties of the meat product [7-9]. Fat reduction can, therefore, increase the toughness of meat products and significantly alter their acceptability $[10,11]$. The incorporation of vegetable oils in meat products to replace animal fat may have a positive effect on consumer health as they are free of cholesterol and have a higher ratio of unsaturated to saturated fatty acids. Moreover, different fiber-rich ingredients have recently been used as a functional additives to numerous ground and emulsified meat products to support and ensure binding. The reduction of animal fat in meat products and the substitution of animal fat with vegetable oils and dietary fibers could result in healthier products [12-14]. 
Of vegetable oils, olive is the one that has received most attention, chiefly as a source of monounsaturated fatty acids. It has a high biological value and contains antioxidant substances in optimum concentrations. Olive oil intake is associated with a lessened risk of heart disease and breast cancer and has positive effects on colon cancer [15-18]. In addition, interest in dietary fiber is a consequence of the belief that it contributes positively to the consumer's health and quality of life due to its physiological effects [19].wheat bran is the most popular source of dietary fiber, with widespread recommendations for prevention and treatment of constipation and diabetes and reducing the risk of certain types of cancer [20-23]. It forms a good source of protein and minerals, in addition to its high fiber content and antioxidant activity $[24,25]$.

On the other hand, meat products constitute a major source for pathogens that cause foodborne illness in human and awareness of risks involving their microbial contamination showed a significant continuous increase. Food irradiation is proven to be the best technology in eliminating disease-causing pathogens from raw meat products [26,27]. Gamma irradiation at dose of $3 \mathrm{kGy}$ can be applied for improving the microbiological safety of raw meat products [28]. Therefore, The objective of this study was to evaluate the quality characteristics of gamma irradiated beefburger formulated by partial replacement of the beef fat with different levels of olive oil and wheat bran fibers.

\section{Materials and Methods}

\subsection{Materials}

Fresh lean beef and beef fat were excised from three beef carcasses at the butcher's shop (after three hours of slaughtering and dressing) to be used for the preparation of burger formulations in three separate trials (3 different replicates). The lean beef cuts were trimmed off any subcutaneous or intramuscular fats as well as thick or connective tissue, being a very lean beef meat. Then the lean beef and beef fat (within each of the different replicates) were ground separately in a meat grinder. Whole wheat bran was obtained from Al-Sharkia Milling Company, Zagazig, Egypt. Defatted soy flour was obtained from the Agricultural Research Center, Ministry of Agriculture, Egypt. Olive oil and the other ingredients of high quality were obtained from a local market.

\subsection{Beefburger Manufacturing}

Five different beefburger formulations (F1-F5) were prepared within each trail replicate (Table 1). The control beefburger formula (F1) consisted of ground lean beef, ground beef fat, soy flour, salt, Sodium tripolyphosphate, dreied onion, spice mixture (black pepper and cumin), and water (within the percentages described by Feiner, [29]). Since a very lean beef cuts with an expected low fat content were used for burger formulation, ground beef fat was added at level of $200 \mathrm{~g} / \mathrm{kg}$ meat batter in the control burger formulation. Then the other burger formulations (F2-F5) were prepared by partial replacement of the beef fat with different percentages of olive oil and wheat bran as shown in Table 1. The ingredients of each of the formulated burger batter were thoroughly mixed by hand and processed into burgers of about $100 \mathrm{~g}$ weight and $10 \mathrm{~cm}$ diameter. The prepared burgers were aerobically packaged (individually) in polyethylene pouches and pouches were sealed by heat.

Table 1. Beefburger formulations with varying levels of beef fat, olive oil, and wheat bran.

\begin{tabular}{|c|c|c|c|c|c|}
\hline \multirow{2}{*}{ Ingredients } & \multicolumn{5}{|c|}{ Amount (g/kg meat batter)/Formulations } \\
\hline & $\mathrm{F} 1$ & $\mathrm{~F} 2$ & F3 & $\mathrm{F} 4$ & F5 \\
\hline Lean beef & 625 & 625 & 625 & 625 & 625 \\
\hline Beef fat & 200 & 100 & 50 & 25 & - \\
\hline Olive oil & - & 50 & 50 & 50 & 50 \\
\hline Whole wheat bran & - & 50 & 100 & 125 & 150 \\
\hline Soy flour (defatted) & 40 & 40 & 40 & 40 & 40 \\
\hline Salt & 15 & 15 & 15 & 15 & 15 \\
\hline Sodium tripolyphosphate & 2 & 2 & 2 & 2 & 2 \\
\hline Dried onion & 3 & 3 & 3 & 3 & 3 \\
\hline $\begin{array}{c}\text { Spice mixture } \\
\text { (Black pepper \& Cumin) }\end{array}$ & 15 & 15 & 15 & 15 & 15 \\
\hline Water & 100 & 100 & 100 & 100 & 100 \\
\hline
\end{tabular}

Formulations: F1, the control meat batter; F2-F5, the different formulations prepared with replacement of beef fat with olive oil and wheat bran. 
The observed burgers were divided into two main portions and immediately transported in an ice chest for irradiation treatment.

\subsection{Irradiation of Samples}

Packaged samples of the prepared beefburger were exposed to gamma irradiation at doses of 0 and $3 \mathrm{kGy}$. Irradiation was carried out at room temperature using an experimental Co-60 source (providing a dose rate of $2.527 \mathrm{kGy} / \mathrm{h}$ ) located at the National Center for Radiation Research and Technology, Nasr City, Cairo, Egypt.

\subsection{Storage and Sampling}

The irradiated and non-irradiated beefburger samples were refrigerated stored at $4^{\circ} \mathrm{C} \pm 1^{\circ} \mathrm{C}$ (except samples for the day zero analysis) and subjected to the periodical analysis at 3 days intervals.

\subsection{Proximate Composition}

Moisture, protein, ash and dietary fibers were determined according to AOAC official methods [30], while total lipids were extracted and determined according to the method of Folch et al. [31]. The remaining of other carbohydrates were calculated by difference.

\subsection{Fatty Acid Profiles}

Fatty acids of the extracted lipids were converted to their methyl esters [32] and the analysis of fatty acid methyl esters (FAME) was accomplished using a 6890 Hewlett Packard gas chromatograph equipped with flam ionization detector. The peak areas and retention times were measured using a Hewlett Packard 3392A integrator. Identification of FAME was based on comparing their relative retention times with those of reference ones.

\subsection{Cooking Yield, Moisture Retention and Fat Retention}

Samples of beefburger were cooked in a preheated electrical grill for 4 min each side, then cooking yield and fat retention were calculated according to Murphy et al. [33], while moisture retention was determined according to El-Magoli et al. [34] using the following equations:

Cooking yield $\%=($ Cooked burger weight $) /($ Uncooked burger weight) $\times 100$

Moisture retention $\%=(\%$ yield $\times \%$ moisture in cooked burger) $/ 100$

Fat retention $\%=[($ Cooked weight $) \times(\%$ fat in cooked burger $) /($ Raw weigt $) \times(\%$ fat in the raw burger $)] \times 100$

\subsection{Measurement of Oxidation}

The extent of oxidation in raw beefburger samples was assessed through the determination of thiobarbituric acid reactive substances (TBARS) using the method of Alasnier et al. [35] and the results were expressed as mg malonaldhyde per kg burger meat.

\subsection{Microbiological Quality}

At time of withdrawal from refrigerated storage, $10 \mathrm{~g}$ aliquots of burger samples were removed aseptically to prepare the initial $1 / 10$ dilution which was used for the preparation of other serial dilutions in $0.1 \%$ peptone water. Then colony forming units for total aerobic mesophelic and psychrophilic bacteria were determined by plating on plate count agar medium and incubation at $30^{\circ} \mathrm{C}$ for 3 days and $7^{\circ} \mathrm{C}$ for 7 days, respectively [36]. Total molds and yeasts were enumerated on malt agar medium after incubation at $25^{\circ} \mathrm{C}$ for 3 - 5 days [36]. Enterobacteriaceae were counted on violet red bile glucose agar medium after incubation at $37^{\circ} \mathrm{C}$ for $20-24 \mathrm{~h}$ [37]. Staphylococcus aureus was counted using Baird-Parker RPF medium after incubation at $35^{\circ} \mathrm{C}$ for $24-48 \mathrm{~h} \mathrm{[38]}$ and confirmed by the coagulase test as described by Collins et al. [39]. The detection of Salmonella was carried out using most probable number technique (MPN) according to ISO [40]. The samples were inoculated into buffer peptone for $24 \mathrm{~h}$ at $37^{\circ} \mathrm{C}$. After enrichment at $37^{\circ} \mathrm{C}$ for $24 \mathrm{~h}$ in selenite broth, the cultures were streaked on brilliant green agar and incubated at $37^{\circ} \mathrm{C}$ for $24 \mathrm{~h}$, then biochemical examination in triple sugar iron agar (TSI) and lysine decarboxilase broth was conducted.

\subsection{Sensory Evaluation}

Raw samples of irradiated and non irradiated beefburger were subjected to sensory evaluation for their color \& appearance and odor post treatment and during refrigerated storage, while the cooked beefburger samples were evaluated for their appearance and color, odor, taste and texture and juiciness on day zero only for safety precautions. In all sensory evaluation tests, the panelists consisted of ten non expert members from our laboratory, while scores were obtained by rating the examined quality attributes using the following rating scale: 9 - excellent, 8-very good, 7-good, 6-below good/ above fair, 5-fair, 4-below fair/above poor, 3-poor, 2-very poor and 1 -extremely poor. Rating of 5 and above indicated an acceptable samples, while rating of 4 indicated that the samples were of marginal quality, whereas rating of 3 and below indicated unacceptable samples [41].

\subsection{Statistical Analysis}

All analyses were performed using three pouches per each separate replicate. Then data were statistically analyzed by using the generalized linear model procedure of 
the SAS software [42], and the differences among means (at $p<0.05$ ) were compared by using Duncan's multiple range test.

\section{Results and Discussion}

\subsection{Proximate Composition}

The results of compositional analysis for the different formulated beefburger samples are given in Table 2 . The percentages of moisture, protein, total lipids, ash, dietary fibers, and carbohydrates in the non-irradiated control burger formula (F1) were 58.76\%, 15.67\%, 20.20\%, $2.72 \%, 1.11 \%$, and $1.54 \%$, respectively. Incorporation of wheat bran into meat batter with the reduction of the added beef fat significantly increased the contents of total fibers and reduced the contents of total lipids for the resultant beefburger formulations, proportionally to the added bran fibers. The total lipids decreased by $20 \%$, $42 \%, 53 \%$, and $64 \%$, while the dietary fibers increased by $206 \%, 412 \%, 514 \%$, and $618 \%$, respectively, in the different formulated burger samples (F2-F5) as compared with the control burger formulation (F1). Much attention has been recently paid to develop meat products with physiological functions to promote health conditions and prevent the risk of diseases [43]. Increased intake of dietary fibers has been recommended for reducing the risk of colon cancer, diabetes, obesity and cardiovascular diseases in human [43-45]. The same results clearly indicate that non of the determined macronutrients for all formulated burger samples showed a significant $(P>$ 0.05 ) changes due to gamma irradiation at dose of $3 \mathrm{kGy}$ (Table 2).

\subsection{Fatty Acid Profiles}

Table 3 represents the fatty acid profiles of lipid sepa- rated from non-irradiated and irradiated beefburger under investigation. Lipids of all non-irradiated burger formulations contained the same fatty acids. However, lipids of the control burger formula (F1) had the highest content of saturated fatty acids (SFA) reaching $51.6 \%$ of the total fatty acids and the predominant SFA were palmitic, stearic, and myristic, respectively. Meanwhile, the total unsaturated fatty acids (UFA) reached $46.05 \%$ and oleic was the most abundant monounsaturated fatty acid, while linoleic and linolenic were the predominant polyunsaturated fatty acids. Similar results were reported for lipids of beef patties [46]. Incorporation of olive oil into the beef batter with decreasing of the added beef fat significantly $(P<0.05)$ decreased the contents of SFA in lipids of the different formulated burger samples accompanied with a significant increase of their USFA content, proportionally to the reduction of the added beef fat. Accordingly, a significant increases $(P<0.05)$ in the ratios of unsaturated/saturated and polyunsaturated/ saturated fatty acids were observed, indicating an improvement of the burger nutritional content (Table 3). Similar observations were reported for the replacement of the animal fat with vegetable oils in different meat products $[12,47]$. Healthier lipid formulation based on processing strategies is one of the most important current approaches to the development of potential meat-based functional foods [16]. It was shown that low-fat, monounsaturated-rich diet reduced the susceptibility of low density lipoprotein peroxidation and may be of therapeutic value in the treatment of hypercholesterolemia [48]. From Table 3, it can be also seen that lipids separated from the irradiated burger samples showed the same phenomenon and trends for their fatty acids similar to that observed for the non-irradiated samples. However, irradiation of the different formulated burger samples induced slight, but sta-

Table 2. Proximate composition of raw non-irradiated and irradiated ( $3 \mathrm{kGy}$ ) beefburger formulated with different levels of beef fat, olive oil, and wheat bran.

\begin{tabular}{|c|c|c|c|c|c|c|c|c|c|c|}
\hline \multirow[b]{2}{*}{ Components } & \multicolumn{10}{|c|}{ Mean $(\mathrm{g} / 100 \mathrm{~g})$} \\
\hline & \multicolumn{5}{|c|}{ Non-irradiated beefburger } & \multicolumn{5}{|c|}{ Irradiated beefburger at $3 \mathrm{kGy}$ dose } \\
\hline Moisture & $58.76 b c$ & $58.71 b c$ & $58.92 \mathrm{abc}$ & $59.02 \mathrm{a}$ & $59.12 \mathrm{a}$ & $58.73 b c$ & $58.70 \mathrm{c}$ & $58.94 \mathrm{ab}$ & $59.10 \mathrm{a}$ & $59.09 \mathrm{a}$ \\
\hline Protein & $15.67 \mathrm{e}$ & $15.92 \mathrm{~d}$ & $16.28 \mathrm{c}$ & $16.46 \mathrm{abc}$ & $16.64 \mathrm{ab}$ & $15.69 \mathrm{e}$ & $15.93 d$ & $16.25 \mathrm{c}$ & $16.44 \mathrm{bc}$ & $16.67 \mathrm{a}$ \\
\hline Total lipids & $20.20 \mathrm{a}$ & $16.15 \mathrm{~b}$ & $11.72 \mathrm{c}$ & $9.51 \mathrm{~d}$ & $7.30 \mathrm{e}$ & $20.22 \mathrm{a}$ & $16.13 b$ & $11.73 \mathrm{c}$ & $9.53 \mathrm{~d}$ & $7.33 \mathrm{e}$ \\
\hline Ash & $2.72 \mathrm{e}$ & $3.01 \mathrm{~d}$ & $3.30 \mathrm{c}$ & $3.44 \mathrm{~b}$ & $3.59 \mathrm{a}$ & $2.71 \mathrm{e}$ & $3.03 \mathrm{~d}$ & $3.29 \mathrm{c}$ & $3.40 \mathrm{~b}$ & $3.61 \mathrm{a}$ \\
\hline Dietary fiber & $1.11 \mathrm{e}$ & $3.40 \mathrm{~d}$ & $5.68 \mathrm{c}$ & $6.82 b$ & $7.97 \mathrm{a}$ & $1.13 \mathrm{e}$ & $3.41 \mathrm{~d}$ & $5.66 \mathrm{c}$ & $6.79 b$ & $7.92 \mathrm{a}$ \\
\hline $\begin{array}{c}\text { Other carbohydrates } \\
\text { by difference }\end{array}$ & $1.54 \mathrm{e}$ & $2.81 \mathrm{~d}$ & $4.10 \mathrm{c}$ & $4.75 b$ & $5.38 \mathrm{a}$ & $1.52 \mathrm{e}$ & $2.80 \mathrm{~d}$ & $4.13 c$ & $4.74 b$ & $5.38 \mathrm{a}$ \\
\hline
\end{tabular}

Means with a different letter within each component are different significantly $(P<0.05)$. 
Table 3. Fatty acid profiles of lipids separated from different formulated non-irradiated and irradiated (3 kGy) beefburger.

\begin{tabular}{|c|c|c|c|c|c|c|c|c|c|c|}
\hline \multirow{3}{*}{ Fatty acids } & \multicolumn{10}{|c|}{ Mean (g/100 g lipids) / Formulations } \\
\hline & \multicolumn{5}{|c|}{ Non-irradiated beefburger } & \multicolumn{5}{|c|}{ Irradiated beefburger at $3 \mathrm{kGy}$ dose } \\
\hline & $\mathrm{F} 1$ & F2 & F3 & F4 & F5 & $\mathrm{F} 1$ & F2 & F3 & F4 & F5 \\
\hline $12: 0$ & $0.62 \mathrm{~b}$ & $0.34 d$ & $0.27 \mathrm{e}$ & $0.21 \mathrm{f}$ & $0.10 \mathrm{~h}$ & $0.71 \mathrm{a}$ & $0.44 \mathrm{c}$ & $0.32 \mathrm{~d}$ & $0.29 \mathrm{e}$ & $0.17 \mathrm{~g}$ \\
\hline $14: 0$ & $4.16 \mathrm{a}$ & $2.73 b$ & $2.14 \mathrm{c}$ & $1.64 \mathrm{~d}$ & $0.83 \mathrm{e}$ & $4.15 \mathrm{a}$ & $2.71 b$ & $2.12 \mathrm{c}$ & $1.62 \mathrm{~d}$ & $0.81 \mathrm{e}$ \\
\hline $15: 0$ & $0.52 \mathrm{a}$ & $0.29 \mathrm{~b}$ & $0.23 \mathrm{c}$ & $0.18 \mathrm{~d}$ & $0.08 \mathrm{e}$ & $0.52 \mathrm{a}$ & $0.28 \mathrm{~b}$ & $0.23 \mathrm{c}$ & $0.17 \mathrm{~d}$ & $0.02 \mathrm{f}$ \\
\hline $16: 0$ & $25.81 \mathrm{a}$ & $20.22 b$ & $18.00 \mathrm{c}$ & $16.13 \mathrm{~d}$ & $13.10 \mathrm{e}$ & $25.88 \mathrm{a}$ & $20.26 \mathrm{~b}$ & $18.02 \mathrm{c}$ & $16.15 \mathrm{~d}$ & $13.12 \mathrm{e}$ \\
\hline $16: 1$ & $3.19 \mathrm{a}$ & $2.32 \mathrm{c}$ & $1.97 \mathrm{~d}$ & $1.66 \mathrm{e}$ & $1.19 \mathrm{f}$ & $3.13 b$ & $2.28 \mathrm{c}$ & $1.95 \mathrm{~d}$ & $1.65 \mathrm{e}$ & $1.18 \mathrm{f}$ \\
\hline $17: 0$ & $1.28 \mathrm{a}$ & $0.88 \mathrm{~b}$ & $0.69 \mathrm{c}$ & $0.29 \mathrm{~d}$ & $0.05 \mathrm{e}$ & $1.29 \mathrm{a}$ & $0.89 \mathrm{~b}$ & $0.68 \mathrm{c}$ & $0.28 \mathrm{~d}$ & $0.06 \mathrm{e}$ \\
\hline $18: 0$ & $18.98 \mathrm{~b}$ & $13.69 \mathrm{~d}$ & $11.31 \mathrm{f}$ & $9.31 \mathrm{~h}$ & $6.06 \mathrm{j}$ & $19.38 \mathrm{a}$ & $14.19 \mathrm{c}$ & $11.58 \mathrm{e}$ & $9.52 \mathrm{~g}$ & $6.27 \mathrm{i}$ \\
\hline $18: 1$ & $38.97 \mathrm{e}$ & $51.41 \mathrm{~d}$ & $55.70 \mathrm{c}$ & $59.34 \mathrm{~b}$ & $65.17 \mathrm{a}$ & $38.99 \mathrm{e}$ & $51.44 \mathrm{~d}$ & $55.72 \mathrm{c}$ & $59.36 \mathrm{~b}$ & $65.19 \mathrm{a}$ \\
\hline $18: 2$ & $3.28 \mathrm{i}$ & $4.69 \mathrm{~g}$ & $6.44 \mathrm{e}$ & $7.94 \mathrm{c}$ & $10.42 \mathrm{a}$ & $2.98 \mathrm{j}$ & $4.25 \mathrm{~h}$ & $6.25 f$ & $7.83 \mathrm{~d}$ & $10.33 b$ \\
\hline $18: 3$ & $0.48 \mathrm{~g}$ & $0.62 \mathrm{e}$ & $0.77 \mathrm{~d}$ & $0.89 \mathrm{c}$ & $1.10 \mathrm{a}$ & $0.20 \mathrm{i}$ & $0.38 \mathrm{~h}$ & $0.59 \mathrm{f}$ & $0.77 \mathrm{~d}$ & $0.99 b$ \\
\hline $20: 0$ & $0.23 \mathrm{ef}$ & $0.22 \mathrm{f}$ & $0.25 \mathrm{~d}$ & $0.28 \mathrm{c}$ & $0.32 \mathrm{a}$ & $0.24 \mathrm{e}$ & $0.23 \mathrm{ef}$ & $0.26 \mathrm{~d}$ & $0.30 \mathrm{~b}$ & $0.33 \mathrm{a}$ \\
\hline $20: 1$ & $0.13 \mathrm{e}$ & $0.19 \mathrm{c}$ & $0.21 \mathrm{~b}$ & $0.22 b$ & $0.25 \mathrm{a}$ & $0.12 \mathrm{e}$ & $0.19 \mathrm{c}$ & $0.20 \mathrm{~b}$ & $0.21 \mathrm{~b}$ & $0.25 \mathrm{a}$ \\
\hline SFA & $51.60 \mathrm{~b}$ & $38.37 \mathrm{~d}$ & $32.89 \mathrm{f}$ & $28.04 \mathrm{~h}$ & $20.54 j$ & $52.17 \mathrm{a}$ & $39.00 \mathrm{c}$ & $33.21 \mathrm{e}$ & $28.33 \mathrm{~g}$ & $20.78 \mathrm{i}$ \\
\hline UFA & $46.05 i$ & $59.23 \mathrm{~g}$ & $65.09 \mathrm{e}$ & $70.05 \mathrm{c}$ & $78.13 \mathrm{a}$ & $45.42 \mathrm{j}$ & $58.57 \mathrm{~h}$ & $64.71 \mathrm{f}$ & $69.82 \mathrm{~d}$ & $77.94 b$ \\
\hline MUFA & $42.29 \mathrm{e}$ & $53.92 \mathrm{~d}$ & $57.88 \mathrm{c}$ & $61.22 \mathrm{~b}$ & $66.61 \mathrm{a}$ & $42.24 \mathrm{e}$ & $53.91 \mathrm{~d}$ & $57.87 \mathrm{c}$ & $61.22 \mathrm{~b}$ & $66.62 \mathrm{a}$ \\
\hline PUFA & $3.76 \mathrm{i}$ & $5.31 \mathrm{~g}$ & $7.21 \mathrm{e}$ & $8.83 \mathrm{c}$ & $11.52 \mathrm{a}$ & $3.18 \mathrm{j}$ & $4.66 \mathrm{~h}$ & $6.84 \mathrm{f}$ & $8.60 \mathrm{~d}$ & $11.32 b$ \\
\hline $\mathrm{U} / \mathrm{S}$ & $0.892 \mathrm{i}$ & $1.544 \mathrm{~g}$ & $1.979 \mathrm{e}$ & $2.498 \mathrm{c}$ & $3.804 \mathrm{a}$ & $0.871 \mathrm{j}$ & $1.50 \mathrm{~h}$ & $1.949 \mathrm{f}$ & $2.465 \mathrm{~d}$ & $3.751 \mathrm{~b}$ \\
\hline $\mathrm{P} / \mathrm{S}$ & $0.073 \mathrm{i}$ & $0.138 \mathrm{~g}$ & $0.219 \mathrm{e}$ & $0.315 \mathrm{c}$ & $0.561 \mathrm{a}$ & $0.061 \mathrm{j}$ & $0.119 \mathrm{~h}$ & $0.203 \mathrm{f}$ & $0.304 \mathrm{~d}$ & $0.545 b$ \\
\hline
\end{tabular}

Means with a different letter within each fatty acid are different significantly $(P<0.05)$; SFA: Saturated fatty acids; UFA: Unsaturated fatty acids; MUFA: Monounsaturated fatty acids; PUFA: Polyunsaturated fatty acids; U/S: Unsaturated/Saturated; P/S: Polyunsaturated/Saturated.

tistically significant $(P<0.05)$, increase in the contents of SFA with corresponding significant decrease in the total UFA in their lipids. Similar results were previously observed [49].

\subsection{Cooking Yield, Moisture Retention and Fat Retention}

The measurements of cooking yield, moisture and fat retention in irradiated and non-irradiated beefburger samples as influenced by formulation with olive oil and wheat bran are summarized in Table 4. Formulation of beefburger with replacement of beef fat with olive oil and wheat bran significantly $(P<0.05)$ improved the cooking yield of samples as well as their moisture and fat retention. The observed improvement was pronounced with increasing the added bran fibers, as shown for the different formulated non-irradiated burger samples. The highest cooking loss was observed for the control formu- lated burger (F1) which may be attributed to the excessive fat separation and water release during cooking. The high ability of wheat fibers, as all other dietary fibers, to keep moisture and fat in the meat matrix of meat products is well documented and these observations are supported by several authors who used different types of fibers in the formulations of burger and other meat products $[12,50,51]$. Furthermore, cooking yield is influenced by the amount and type of fat in the meat product $[52,53]$. Reducing the animal fat content by replacement with vegetable oil increased the cooking yield of meat products [54]. Neither irradiation at $3 \mathrm{kGy}$ nor refrigerated storage $\left(4^{\circ} \mathrm{C} \pm 1^{\circ} \mathrm{C}\right)$ could significantly $(P>0.05)$ affect cooking and binding properties of the different formulated beefburger samples under investigation. As shown, no significant differences $(P>0.05)$ were observed between the measurements of cooking yield, moisture retention and fat retention for irradiated and 
Table 4. Cooking yield, moisture retention and fat retention during refrigerated storage of non-irradiated and irradiated (3 kGy) beefburger as affected by formulation with olive oil and wheat bran.

\begin{tabular}{|c|c|c|c|c|c|c|c|c|c|c|}
\hline \multirow{3}{*}{$\begin{array}{c}\text { Storage } \\
\text { (Days) }\end{array}$} & \multicolumn{10}{|c|}{ Parameter/mean (\%) } \\
\hline & \multicolumn{5}{|c|}{ Non-irradiated beefburger } & \multicolumn{5}{|c|}{ Irradiated beefburger at $3 \mathrm{kGy}$ dose } \\
\hline & $\mathrm{F} 1$ & $\mathrm{~F} 2$ & F3 & F4 & F5 & $\mathrm{F} 1$ & $\mathrm{~F} 2$ & F3 & $\mathrm{F} 4$ & F5 \\
\hline \multicolumn{11}{|c|}{ Cooking yield } \\
\hline 0 & $76.45 \mathrm{e}$ & $80.84 d$ & $85.23 \mathrm{c}$ & $87.43 b$ & $89.62 \mathrm{a}$ & $76.52 \mathrm{e}$ & $80.79 \mathrm{~d}$ & $85.30 \mathrm{c}$ & $87.63 \mathrm{~b}$ & $89.73 \mathrm{a}$ \\
\hline 3 & $75.98 \mathrm{e}$ & $81.02 \mathrm{~d}$ & $84.71 \mathrm{c}$ & $87.88 \mathrm{~b}$ & $88.77 \mathrm{a}$ & $76.16 \mathrm{e}$ & $79.94 d$ & $85.41 \mathrm{c}$ & $87.31 \mathrm{~b}$ & $88.93 \mathrm{a}$ \\
\hline 6 & $76.53 \mathrm{e}$ & $80.65 \mathrm{~d}$ & $85.60 \mathrm{c}$ & $87.22 \mathrm{~b}$ & $89.11 \mathrm{a}$ & $75.89 \mathrm{e}$ & $81.22 \mathrm{~d}$ & $85.71 \mathrm{c}$ & $88.02 \mathrm{~b}$ & $89.80 \mathrm{a}$ \\
\hline 9 & $77.01 \mathrm{e}$ & $80.44 d$ & $85.03 \mathrm{c}$ & $88.07 \mathrm{~b}$ & $89.44 a$ & $76.32 \mathrm{e}$ & $80.36 \mathrm{~d}$ & $85.13 \mathrm{c}$ & $87.70 \mathrm{~b}$ & $89.33 \mathrm{a}$ \\
\hline 12 & ( & (®) & ${ }^{\circledR}$ & ( & ( & $76.88 \mathrm{e}$ & $80.72 \mathrm{~d}$ & $84.95 \mathrm{c}$ & $87.10 \mathrm{~b}$ & $88.78 \mathrm{a}$ \\
\hline \multicolumn{11}{|c|}{ Moisture retention } \\
\hline 0 & $65.49 \mathrm{e}$ & $69.25 \mathrm{~d}$ & $73.01 \mathrm{c}$ & $74.90 \mathrm{~b}$ & $76.03 \mathrm{a}$ & $65.61 \mathrm{e}$ & $69.16 \mathrm{~d}$ & $72.88 \mathrm{c}$ & $75.11 \mathrm{~b}$ & $76.22 \mathrm{a}$ \\
\hline 3 & $66.11 \mathrm{e}$ & $68.92 d$ & $73.32 \mathrm{c}$ & $75.11 \mathrm{~b}$ & $75.89 a$ & $66.18 \mathrm{e}$ & $68.88 \mathrm{~d}$ & $73.05 \mathrm{c}$ & $74.79 b$ & $76.51 \mathrm{a}$ \\
\hline 6 & $65.72 \mathrm{e}$ & $69.03 \mathrm{~d}$ & $72.91 \mathrm{c}$ & $44.79 b$ & $76.11 \mathrm{a}$ & $66.01 \mathrm{e}$ & $68.91 \mathrm{~d}$ & $73.00 \mathrm{c}$ & $75.21 \mathrm{~b}$ & $75.93 a$ \\
\hline 9 & $65.38 \mathrm{e}$ & $69.43 \mathrm{~d}$ & $73.00 \mathrm{c}$ & $75.01 \mathrm{~b}$ & $76.00 \mathrm{a}$ & $65.70 \mathrm{e}$ & $69.22 \mathrm{~d}$ & $72.73 \mathrm{c}$ & $75.00 \mathrm{~b}$ & $76.27 \mathrm{a}$ \\
\hline 12 & ( & ( & ${ }^{\circledR}$ & ( & ( & $65.22 \mathrm{e}$ & $69.07 \mathrm{~d}$ & $72.91 \mathrm{c}$ & $74.92 b$ & $76.03 \mathrm{a}$ \\
\hline \multicolumn{11}{|c|}{ Fat retention } \\
\hline 0 & $71.29 \mathrm{e}$ & $75.38 \mathrm{~d}$ & $79.48 \mathrm{c}$ & $81.53 b$ & $85.06 \mathrm{a}$ & $70.92 \mathrm{e}$ & $75.52 \mathrm{~d}$ & $78.89 \mathrm{c}$ & $82.01 \mathrm{~b}$ & $84.93 a$ \\
\hline 3 & $70.99 \mathrm{e}$ & $75.76 \mathrm{~d}$ & $78.84 \mathrm{c}$ & $81.30 \mathrm{~b}$ & $84.93 a$ & $71.02 \mathrm{e}$ & $75.38 \mathrm{~d}$ & $78.66 \mathrm{c}$ & $82.17 \mathrm{~b}$ & $85.03 \mathrm{a}$ \\
\hline 6 & $71.00 \mathrm{e}$ & $75.22 \mathrm{~d}$ & $79.53 \mathrm{c}$ & $81.72 \mathrm{~b}$ & $85.00 \mathrm{a}$ & $71.13 \mathrm{e}$ & $76.02 \mathrm{~d}$ & $79.01 \mathrm{c}$ & $81.94 b$ & $85.14 \mathrm{a}$ \\
\hline 9 & $71.42 \mathrm{e}$ & $75.13 \mathrm{~d}$ & $79.31 \mathrm{c}$ & $81.25 b$ & $85.13 \mathrm{a}$ & $70.91 \mathrm{e}$ & $75.65 \mathrm{~d}$ & $78.74 \mathrm{c}$ & $82.00 \mathrm{~b}$ & $84.89 \mathrm{a}$ \\
\hline 12 & ( & (®) & ( & ( & ( & $71.00 \mathrm{e}$ & $75.41 \mathrm{~d}$ & $79.00 \mathrm{c}$ & $82.13 b$ & $85.00 \mathrm{a}$ \\
\hline
\end{tabular}

Means with a different letter within each parameter are different significantly $(P<0.05)$; $®$ : Rejected and their values were discarded after statistical analysis.

non-irradiated beefburger samples post treatment and during refrigerated storage at $4{ }^{\circ} \mathrm{C} \pm 1{ }^{\circ} \mathrm{C}$ (Table 4).

\subsection{Extent of Oxidation}

The development of oxidation during refrigerated storage $\left(4^{\circ} \mathrm{C} \pm 1^{\circ} \mathrm{C}\right)$ of the different formulated irradiated and non-irradiated beefburger samples was assessed through the measurement of TBARS values (Table 5). On day zero, the different formulated non-irradiated beefburger samples had an initial TBARS values of $0.23,0.19,0.17$, 0.14 and $0.13 \mathrm{mg}$ malonaldehyde $/ \mathrm{kg}$ burger meat, respectively, showing the highest value for the control formulated burger (F1). The oxidative reactions are enhanced in meat products after mincing and restructuring as well as during refrigerated storage due to the interaction of unsaturated fatty acids with prooxidants [55]. Irradiation of the different formulated beefburger samples at $3 \mathrm{kGy}$ dose significantly $(P<0.05)$ increased their
TBARS and the control formulated burger samples showed also the highest value. Moreover, subsequent refrigerated storage of the different formulated beefburger samples significantly $(P<0.05)$ increased their TBARS values for both irradiated and non-irradiated samples showing a higher values in the irradiated samples (Table 5). The oxidation of lipids due to irradiation and aerobic storage of meat products was previously reported by several authors $[27,56]$. As can be seen, the extent of oxidation significantly decreased with increaseing the added wheat bran in both non-irradiated and irradiated burger samples and also post irradiation and during storage, indicating the presence of enhanced antioxidant activity with increasing of the added bran fibers. The observed antioxidant activity was also apparent during the formulation of the burger batter as indicated by the significant decrease in the initial TBARS values with increasing of the added wheat bran for the different 
Table 5. TBARS values for raw non-irradiated and irradiated ( $3 \mathrm{kGy}$ ) beefburger formulated with different levels of beef fat, olive oil, and wheat bran.

\begin{tabular}{|c|c|c|c|c|c|c|c|c|c|c|}
\hline \multirow{3}{*}{ Storage (Days) } & \multicolumn{10}{|c|}{ Mean (mg malonaldehyde/kg burger meat)/Formulations } \\
\hline & \multicolumn{5}{|c|}{ Non-irradiated beefburger } & \multicolumn{5}{|c|}{ Irradiated beefburger at $3 \mathrm{kGy}$ dose } \\
\hline & $\mathrm{F} 1$ & $\mathrm{~F} 2$ & F3 & $\mathrm{F} 4$ & F5 & F1 & $\mathrm{F} 2$ & F3 & F4 & F5 \\
\hline 0 & $0.23 \mathrm{r}$ & 0.19 rs & $0.17 \mathrm{st}$ & $0.14 \mathrm{st}$ & $0.13 \mathrm{t}$ & $0.52 \mathrm{kl}$ & $0.44 \mathrm{mn}$ & 0.40 no & $0.34 \mathrm{pq}$ & $0.29 \mathrm{qr}$ \\
\hline 3 & 0.41 no & $0.34 \mathrm{pq}$ & $0.29 \mathrm{qr}$ & $0.25 \mathrm{r}$ & $0.23 \mathrm{r}$ & $0.63 \mathrm{gh}$ & $0.54 \mathrm{jk}$ & $0.47 \mathrm{~lm}$ & 0.40 no & $0.34 \mathrm{pq}$ \\
\hline 6 & 0.59 hij & $0.48 \mathrm{~lm}$ & $0.44 \mathrm{mn}$ & $0.37 \mathrm{op}$ & $0.32 \mathrm{pq}$ & $0.81 \mathrm{ef}$ & $0.67 \mathrm{~g}$ & 0.61ghi & $0.52 \mathrm{kl}$ & $0.45 \mathrm{~m}$ \\
\hline 9 & $0.76 \mathrm{f}$ & 0.62 ghi & $0.57 \mathrm{ijk}$ & $0.48 \mathrm{~lm}$ & $0.43 \mathrm{mn}$ & $1.00 \mathrm{~d}$ & $0.84 \mathrm{e}$ & $0.76 \mathrm{f}$ & $0.65 \mathrm{~g}$ & $0.56 \mathrm{ijk}$ \\
\hline 12 & (®) & (®) & (R) & (®) & (B) & $1.51 \mathrm{a}$ & $1.29 \mathrm{~b}$ & $1.12 \mathrm{c}$ & $0.80 \mathrm{ef}$ & $0.83 \mathrm{e}$ \\
\hline
\end{tabular}

Means with a different letter are different significantly $(P<0.05)$; ${ }^{\circledR}$ : Rejected and their values were discarded after statistical analysis.

non-irradiated burger samples on day zero (Table 5). The observed antioxidant activity may be attributed to the added wheat bran fibers. It has been illustrated that wheat bran contains high total phenolic contents with high radical scavenging capability and antioxidant activity [25]. Furthermore, olive oil, virgin and refined, contains also phenolic compounds with high antioxidant power [18].

\subsection{Microbiological Quality}

The results in Table 6 reveal a high initial microbial contamination in addition to the presence of Staphylococcus aureus and Salmonella in all formulated non-irradiated burger samples. It is well established that meats and meat products contain a broad spectrum of microorganisms and constitute a major source for foodborne pathogens [26]. Irradiation of all formulated beefburger samples at dose of $3 \mathrm{kGy}$ appeared to be effective in improving the microbiological quality of samples. The chosen dose effectively destroyed the present Staphylococcus aureus and Salmonella, which were not detected in the irradiated samples post irradiation and during their refrigerated storage. This is in addition to the observed significant reduction in the counts of mesophelic and psychrophilic bacteria as well as molds and yeasts (Table 6) leading to the achievement of a duple refrigerated shelf life (data not presented). Irradiation is among the most effective physical decontamination technologies for inactivating foodborne pathogens and improving the safety of meats [26] and the effectiveness of such irradiation dose in improving the microbial safety of other meat products was also previously observed $[57,58]$.

\subsection{Sensory Properties}

On day zero, the sensory evaluation of raw non-irradiated beefburger samples indicated that formulation of burger with olive oil and wheat bran had no adverse effects on the acceptability of their color and appearance as well as their odor. As shown in Table 7, the different formulated non-irradiated burger samples had a similar scores showing no significant differences between their sensory acceptability. The same results further show that irradiation and refrigerated storage $\left(4^{\circ} \mathrm{C} \pm 1{ }^{\circ} \mathrm{C}\right)$ of the different formulated beefburger samples has no significant effect on the acceptability of these sensory attributes as all raw irradiated samples showed a similar high scores compared to the non-irradiated samples except that all nonirradiated burger samples showed a rejection sensory scores for their odor due to the detection of a putrid off-odor on day 12 of their storage (Table 7). Sensory evaluation was also carried out for the cooked burger samples and the sensory traits for cooked samples of the different formulated non-irradiated and irradiated beefburger are given in Table $\mathbf{8}$. Ratings by the sensory panel showed that there were no significant differences between the acceptability of the control formulated burger and those formulated with olive oil and wheat bran except the fifth formulated burger samples (that prepared with the highest addition of wheat) which showed a significantly lower score for their odor and taste, but were still acceptable, due to the absence of the beef fat. The same observations were recorded for the cooked irradiated burger samples indicating that irradiation of raw beefburger samples at the applied dose had no significant effects on their acceptability after cooking, showing a similar preference scores as compared with the non-irradiated samples (Table 8). These results show that formulation of beefburger with partial replacement of beef fat with olive oil and wheat bran produced acceptable samples compared to the control formulated burger samples with a consistent texture, adequate juiciness and good flavor. Wheat fiber is neutral in taste and help to retain 
Table 6. Microbiological quality of the different formulated beefburger samples as affected by irradiation at dose of $3 \mathrm{kGy}$ and refrigerated storage $\left(4^{\circ} \mathrm{C} \pm 1^{\circ} \mathrm{C}\right)$.

\begin{tabular}{|c|c|c|c|c|c|c|c|c|c|c|}
\hline \multirow{3}{*}{$\begin{array}{l}\text { Storage } \\
\text { (Days) }\end{array}$} & \multicolumn{10}{|c|}{ Determination/Formulations } \\
\hline & \multicolumn{5}{|c|}{ Non-irradiated beefburger } & \multicolumn{5}{|c|}{ Irradiated beefburger at $3 \mathrm{kGy}$ dose } \\
\hline & $\mathrm{F} 1$ & $\mathrm{~F} 2$ & F3 & F4 & F5 & $\mathrm{F} 1$ & $\mathrm{~F} 2$ & F3 & F4 & F5 \\
\hline \multicolumn{11}{|c|}{ Aerobic mesophilic bacteria (mean $\log _{10} \mathrm{cfu} / \mathrm{g}$ ) } \\
\hline 0 & $6.01 \mathrm{~d}$ & $6.04 \mathrm{~d}$ & $6.08 \mathrm{~d}$ & $6.10 \mathrm{~d}$ & $6.11 \mathrm{~d}$ & $3.88 \mathrm{~h}$ & $3.89 \mathrm{~h}$ & $3.88 \mathrm{~h}$ & $3.89 \mathrm{~h}$ & $3.89 \mathrm{~h}$ \\
\hline 3 & $6.27 \mathrm{c}$ & $6.28 \mathrm{c}$ & $6.32 \mathrm{c}$ & $6.35 \mathrm{c}$ & $6.36 \mathrm{c}$ & $3.94 \mathrm{~g}$ & $3.94 \mathrm{~g}$ & $3.94 \mathrm{~g}$ & $3.94 \mathrm{~g}$ & $3.95 \mathrm{~g}$ \\
\hline 6 & $6.65 b$ & $6.66 \mathrm{~b}$ & $6.89 \mathrm{~b}$ & $6.67 \mathrm{~b}$ & $6.68 \mathrm{~b}$ & $3.99 \mathrm{~g}$ & $3.99 \mathrm{~g}$ & $4.00 \mathrm{~g}$ & $3.99 \mathrm{~g}$ & $4.01 \mathrm{~g}$ \\
\hline 9 & $6.93 \mathrm{a}$ & $6.95 \mathrm{a}$ & $6.95 \mathrm{a}$ & $6.96 \mathrm{a}$ & $6.97 \mathrm{a}$ & $4.08 \mathrm{f}$ & $4.04 \mathrm{f}$ & $4.09 \mathrm{f}$ & $4.07 \mathrm{f}$ & $4.13 \mathrm{f}$ \\
\hline 12 & ( & (®) & ( & ( & ( & $4.32 \mathrm{e}$ & $4.36 \mathrm{e}$ & $4.34 \mathrm{e}$ & $4.36 \mathrm{e}$ & $4.37 \mathrm{e}$ \\
\hline \multicolumn{11}{|c|}{ Total psychrophilic bacteria (mean $\log _{10} \mathrm{cfu} / \mathrm{g}$ ) } \\
\hline 0 & $5.84 \mathrm{~d}$ & $5.85 \mathrm{~d}$ & $5.45 \mathrm{~d}$ & $5.85 \mathrm{~d}$ & $5.86 \mathrm{~d}$ & $3.45 \mathrm{~h}$ & $3.48 \mathrm{~h}$ & $3.46 \mathrm{~h}$ & $3.48 \mathrm{~h}$ & $3.51 \mathrm{~h}$ \\
\hline 3 & $5.95 \mathrm{c}$ & $5.96 \mathrm{c}$ & $5.99 \mathrm{c}$ & $6.04 \mathrm{c}$ & $6.00 \mathrm{c}$ & $3.51 \mathrm{~g}$ & $3.53 \mathrm{~g}$ & $3.52 \mathrm{~g}$ & $3.58 \mathrm{~g}$ & $3.66 \mathrm{~g}$ \\
\hline 6 & $6.00 \mathrm{~b}$ & $6.30 \mathrm{~b}$ & $6.32 b$ & $6.33 b$ & $6.29 b$ & $3.60 \mathrm{~g}$ & $3.63 \mathrm{~g}$ & $3.65 \mathrm{~g}$ & $3.65 \mathrm{~g}$ & $3.69 \mathrm{~g}$ \\
\hline 9 & $6.59 \mathrm{a}$ & $6.60 \mathrm{a}$ & $6.61 \mathrm{a}$ & $6.61 \mathrm{a}$ & $6.60 \mathrm{a}$ & $3.91 \mathrm{f}$ & $3.90 \mathrm{f}$ & $3.91 \mathrm{f}$ & $3.93 \mathrm{f}$ & $3.93 \mathrm{f}$ \\
\hline 12 & (R) & ( & ( & ( & ( & $4.04 \mathrm{e}$ & $4.11 \mathrm{e}$ & $4.09 \mathrm{e}$ & $4.12 \mathrm{e}$ & $4.15 \mathrm{e}$ \\
\hline \multicolumn{11}{|c|}{ Molds and yeasts (mean $\log _{10} \mathrm{cfu} / \mathrm{g}$ ) } \\
\hline 0 & $4.90 \mathrm{~d}$ & $4.91 \mathrm{~d}$ & $4.92 \mathrm{~d}$ & $4.92 \mathrm{~d}$ & $4.93 \mathrm{~d}$ & $3.68 \mathrm{~g}$ & $3.67 \mathrm{~g}$ & $3.69 \mathrm{~g}$ & $3.69 \mathrm{~g}$ & $3.68 \mathrm{~g}$ \\
\hline 3 & $4.99 \mathrm{c}$ & $5.00 \mathrm{c}$ & $5.01 \mathrm{c}$ & $4.07 \mathrm{c}$ & $5.09 \mathrm{c}$ & $3.72 \mathrm{~g}$ & $3.70 \mathrm{~g}$ & $3.72 \mathrm{~g}$ & $3.71 \mathrm{~g}$ & $3.72 \mathrm{~g}$ \\
\hline 6 & $5.15 b$ & $5.18 \mathrm{~b}$ & $5.20 \mathrm{~b}$ & $5.23 \mathrm{~b}$ & $5.26 \mathrm{~b}$ & $3.76 \mathrm{~g}$ & $3.75 \mathrm{~g}$ & $3.76 \mathrm{~g}$ & $3.76 \mathrm{~g}$ & $3.76 \mathrm{~g}$ \\
\hline 9 & $5.32 \mathrm{a}$ & $5.34 \mathrm{a}$ & $5.35 \mathrm{a}$ & $5.37 \mathrm{a}$ & $5.39 \mathrm{a}$ & $3.85 f$ & $3.86 \mathrm{f}$ & $3.86 \mathrm{f}$ & $3.86 \mathrm{f}$ & $3.86 \mathrm{f}$ \\
\hline 12 & ( & ${ }^{\circledR}$ & ( & ( & ( & $4.00 \mathrm{e}$ & $4.00 \mathrm{e}$ & $4.05 \mathrm{e}$ & $4.06 \mathrm{e}$ & $4.08 \mathrm{e}$ \\
\hline \multicolumn{11}{|c|}{ Enterobacteriaceae (mean $\log _{10} \mathrm{cfu} / \mathrm{g}$ ) } \\
\hline 0 & $4.78 \mathrm{~d}$ & $4.78 \mathrm{~d}$ & $4.79 \mathrm{~d}$ & $4.79 \mathrm{~d}$ & $4.78 \mathrm{~d}$ & ND & ND & ND & ND & ND \\
\hline 3 & $4.85 \mathrm{c}$ & $4.85 \mathrm{c}$ & $4.85 \mathrm{c}$ & $4.85 \mathrm{c}$ & $4.86 \mathrm{c}$ & ND & ND & ND & ND & ND \\
\hline 6 & $4.97 \mathrm{~b}$ & $4.98 \mathrm{~b}$ & $4.98 \mathrm{~b}$ & $4.98 \mathrm{~b}$ & $4.98 \mathrm{~b}$ & ND & ND & ND & ND & ND \\
\hline 9 & $5.08 \mathrm{a}$ & $5.09 \mathrm{a}$ & $5.11 \mathrm{a}$ & $5.11 \mathrm{a}$ & $5.10 \mathrm{a}$ & ND & ND & ND & ND & ND \\
\hline 12 & ( & ( & ( & ( & (®) & ND & ND & ND & ND & ND \\
\hline \multicolumn{11}{|c|}{ Staphylococcus aureus (mean $\log _{10} \mathrm{cfu} / \mathrm{g}$ ) } \\
\hline 0 & $3.94 d$ & $3.95 \mathrm{~d}$ & $3.95 \mathrm{~d}$ & $3.96 \mathrm{~d}$ & $3.94 \mathrm{~d}$ & ND & ND & ND & ND & ND \\
\hline 3 & $4.03 \mathrm{c}$ & $4.08 \mathrm{c}$ & $4.06 \mathrm{c}$ & $4.05 c$ & $4.08 \mathrm{c}$ & ND & ND & ND & ND & ND \\
\hline 6 & $4.13 b$ & $4.17 \mathrm{~b}$ & $4.12 b$ & $4.13 b$ & $4.15 b$ & ND & ND & ND & ND & ND \\
\hline 9 & $4.26 \mathrm{a}$ & $4.30 \mathrm{a}$ & $4.28 \mathrm{a}$ & $4.28 \mathrm{a}$ & $4.30 \mathrm{a}$ & ND & ND & ND & ND & ND \\
\hline 12 & ( & ( & ( & ( & ( & ND & ND & ND & ND & ND \\
\hline \multicolumn{11}{|c|}{ Presence of Salmonella } \\
\hline 0 & $+\mathrm{ve}$ & $+\mathrm{ve}$ & $+\mathrm{ve}$ & $+\mathrm{ve}$ & $+\mathrm{ve}$ & $-\mathrm{ve}$ & $-\mathrm{ve}$ & $-\mathrm{ve}$ & $-\mathrm{ve}$ & $-\mathrm{ve}$ \\
\hline 3 & $+\mathrm{ve}$ & $+\mathrm{ve}$ & $+\mathrm{ve}$ & $+\mathrm{ve}$ & $+\mathrm{ve}$ & $-\mathrm{ve}$ & $-\mathrm{ve}$ & $-\mathrm{ve}$ & $-\mathrm{ve}$ & $-\mathrm{ve}$ \\
\hline 6 & $+\mathrm{ve}$ & $+\mathrm{ve}$ & $+\mathrm{ve}$ & $+\mathrm{ve}$ & $+\mathrm{ve}$ & $-\mathrm{ve}$ & $-\mathrm{ve}$ & $-\mathrm{ve}$ & $-\mathrm{ve}$ & $-\mathrm{ve}$ \\
\hline 9 & $+\mathrm{ve}$ & $+\mathrm{ve}$ & $+\mathrm{ve}$ & $+\mathrm{ve}$ & $+\mathrm{ve}$ & $-\mathrm{ve}$ & $-\mathrm{ve}$ & $-\mathrm{ve}$ & $-\mathrm{ve}$ & $-\mathrm{ve}$ \\
\hline 12 & ${ }^{\circledR}$ & ${ }^{\circledR}$ & ( & (®) & (®) & $-\mathrm{ve}$ & $-\mathrm{ve}$ & $-\mathrm{ve}$ & $-\mathrm{ve}$ & $-\mathrm{ve}$ \\
\hline
\end{tabular}

Means with a different letter within each determination are different significantly $(P<0.05)$; cfu: colony forming unit; ND: Not detected. + ve: Positive. - ve: Negative; ${ }^{\circledR}$ : Rejected and their values were discarded after statistical analysis. 
Table 7. Sensory attributes for raw non-irradiated and irradiated beefburger formulated with different levels of beef fat, olive oil and wheat bran.

\begin{tabular}{|c|c|c|c|c|c|c|c|c|c|c|}
\hline \multirow{3}{*}{$\begin{array}{l}\text { Storage } \\
\text { (Days) }\end{array}$} & \multicolumn{10}{|c|}{ Mean of scores/formulations } \\
\hline & \multicolumn{5}{|c|}{ Non-irradiated beefburger } & \multicolumn{5}{|c|}{ Irradiated beefburger at $3 \mathrm{kGy}$ dose } \\
\hline & $\mathrm{F} 1$ & $\mathrm{~F} 2$ & F3 & F4 & F5 & $\mathrm{F} 1$ & F2 & F3 & $\mathrm{F} 4$ & F5 \\
\hline \multicolumn{11}{|c|}{ Color and appearance } \\
\hline 0 & $7.8 \mathrm{a}$ & $7.6 \mathrm{a}$ & $7.9 \mathrm{a}$ & $7.5 \mathrm{a}$ & $7.4 \mathrm{a}$ & $7.5 \mathrm{a}$ & $7.7 \mathrm{a}$ & $7.5 \mathrm{a}$ & $7.8 \mathrm{a}$ & $7.7 \mathrm{a}$ \\
\hline 3 & $7.6 \mathrm{a}$ & $7.8 \mathrm{a}$ & $7.6 \mathrm{a}$ & $7.9 \mathrm{a}$ & $7.4 \mathrm{a}$ & $7.4 \mathrm{a}$ & $7.9 \mathrm{a}$ & $7.7 \mathrm{a}$ & $7.9 \mathrm{a}$ & $7.6 \mathrm{a}$ \\
\hline 6 & $7.3 \mathrm{a}$ & $7.6 \mathrm{a}$ & $7.4 \mathrm{a}$ & $7.5 \mathrm{a}$ & $7.6 \mathrm{a}$ & $7.9 \mathrm{a}$ & $7.4 \mathrm{a}$ & $7.6 \mathrm{a}$ & $7.4 \mathrm{a}$ & $7.8 \mathrm{a}$ \\
\hline 9 & $7.5 \mathrm{a}$ & $7.4 \mathrm{a}$ & $7.7 \mathrm{a}$ & $7.4 \mathrm{a}$ & $7.8 \mathrm{a}$ & $7.7 \mathrm{a}$ & $7.6 \mathrm{a}$ & $7.7 \mathrm{a}$ & $7.5 \mathrm{a}$ & $7.4 \mathrm{a}$ \\
\hline 12 & $7.6 \mathrm{a}$ & $7.5 \mathrm{a}$ & 7.6a & $7.4 \mathrm{a}$ & $7.6 \mathrm{a}$ & $7.8 \mathrm{a}$ & $7.6 \mathrm{a}$ & $7.7 \mathrm{a}$ & $7.5 \mathrm{a}$ & $7.7 \mathrm{a}$ \\
\hline \multicolumn{11}{|c|}{ Odor } \\
\hline 0 & 7.6a & $7.3 \mathrm{a}$ & $7.5 \mathrm{a}$ & $7.7 \mathrm{a}$ & $7.6 \mathrm{a}$ & $7.5 \mathrm{a}$ & $7.7 \mathrm{a}$ & $7.5 \mathrm{a}$ & $7.8 \mathrm{a}$ & $7.5 \mathrm{a}$ \\
\hline 3 & $7.0 \mathrm{a}$ & $7.6 \mathrm{a}$ & 7.3a & $7.5 \mathrm{a}$ & $7.4 \mathrm{a}$ & $7.7 \mathrm{a}$ & $7.4 \mathrm{a}$ & $7.6 \mathrm{a}$ & $7.9 \mathrm{a}$ & $7.2 \mathrm{a}$ \\
\hline 6 & $7.4 \mathrm{a}$ & $7.6 \mathrm{a}$ & $7.5 \mathrm{a}$ & $7.3 \mathrm{a}$ & $7.7 \mathrm{a}$ & $7.3 \mathrm{a}$ & $7.7 \mathrm{a}$ & $7.2 \mathrm{a}$ & $7.8 \mathrm{a}$ & $7.7 \mathrm{a}$ \\
\hline 9 & $6.9 \mathrm{a}$ & $7.0 \mathrm{a}$ & $7.2 \mathrm{a}$ & $7.1 \mathrm{a}$ & $6.9 \mathrm{a}$ & $7.6 a$ & $7.3 \mathrm{a}$ & $7.6 \mathrm{a}$ & $7.4 \mathrm{a}$ & $7.7 \mathrm{a}$ \\
\hline 12 & $2.3 b$ & $2.5 \mathrm{~b}$ & $2.5 \mathrm{~b}$ & $2.2 \mathrm{~b}$ & $2.4 \mathrm{~b}$ & $7.5 \mathrm{a}$ & $7.4 \mathrm{a}$ & $7.7 \mathrm{a}$ & $7.8 \mathrm{a}$ & $7.4 \mathrm{a}$ \\
\hline
\end{tabular}

Means with a different letter within each of attributes are different significantly $(P<0.05)$.

Table 8. Sensory attributes for cooked non-irradiated and irradiated beefburger formulated with different levels of beef fat, olive oil and wheat bran.

\begin{tabular}{|c|c|c|c|c|c|c|c|c|c|c|}
\hline \multirow[b]{2}{*}{ Sensory attributes } & \multicolumn{10}{|c|}{ Mean of scores/formulations } \\
\hline & \multicolumn{5}{|c|}{ Non-irradiated beefburger } & \multicolumn{5}{|c|}{ Irradiated beefburger at $3 \mathrm{kGy}$ dose } \\
\hline Appearance \& color & $8.1 \mathrm{a}$ & $7.9 \mathrm{a}$ & $8.0 \mathrm{a}$ & $8.3 \mathrm{a}$ & $7.8 \mathrm{a}$ & $8.0 \mathrm{a}$ & $8.2 \mathrm{a}$ & $7.8 \mathrm{a}$ & $7.7 \mathrm{a}$ & $8.3 \mathrm{a}$ \\
\hline Odor & $8.2 \mathrm{a}$ & $8.0 \mathrm{a}$ & $7.9 \mathrm{a}$ & $7.5 \mathrm{a}$ & $5.8 \mathrm{~b}$ & $8.0 \mathrm{a}$ & $8.1 \mathrm{a}$ & $7.6 \mathrm{a}$ & $7.6 \mathrm{a}$ & $5.9 \mathrm{~b}$ \\
\hline Taste & $8.0 \mathrm{a}$ & $7.9 \mathrm{a}$ & $7.8 \mathrm{a}$ & $7.7 \mathrm{a}$ & $5.4 \mathrm{~b}$ & $8.3 \mathrm{a}$ & $8.2 \mathrm{a}$ & $7.8 \mathrm{a}$ & $7.4 \mathrm{a}$ & $5.2 \mathrm{~b}$ \\
\hline Texture $\&$ juiciness & $8.2 \mathrm{a}$ & $7.8 \mathrm{a}$ & $8.1 \mathrm{a}$ & $8.1 \mathrm{a}$ & $7.9 \mathrm{a}$ & $8.1 \mathrm{a}$ & 7.9a & $8.3 \mathrm{a}$ & $8.0 \mathrm{a}$ & $8.2 \mathrm{a}$ \\
\hline
\end{tabular}

Means with a different letter within each of attributes are different significantly $(P<0.05)$.

moisture and fat leading to producing of a more succulent and juicy meat product [29]. The results of sensory traits for the cooked burger samples agree with those observed for cooking and binding measurements in this study.

\section{Conclusions}

It could be concluded that reducing beef fat levels with the addition of olive oil and wheat bran fibers produced a highly acceptable beefburger product with improved nutritional content and cooking and binding properties. Furthermore, irradiation of the resultant beefburger sam- ples at dose of $3 \mathrm{kGy}$ improved their microbiological quality through the complete inactivation of Staphylococcus aureus, Salmonella and enterobacteriaceae, in addition to the significant reduction in the counts of mesophilic and psychrophilic bacteria as well as molds and yeasts, thus, produced a safe beefburger products without any adverse effects on their other quality characteristics.

\section{REFERENCES}

[1] L. Day, R. B. Seymour, K. F. Pitts, I. Konczak and L. Lundin, "Incorporation of Functional Ingredients into Foods," Trends in Food Science \& Technology, Vol. 20, 
No. 9, 2009, pp. 388-395.

doi:10.1016/j.tifs.2008.05.002

[2] S. S. Moon, S. K. Jin, K. H. Hah and I. S. Kim, "Effects of Replacing Backfat with Fat Replacers and Olive Oil on the Quality Characteristics and Lipid Oxidation of Low-Fat Sausage during Storage," Food Science and Biotechnology, Vol. 17, No. 2, 2008, pp. 396-401.

[3] E. B. Ozvural and H. Vural, "Utilization of Interesterified Oil Blends in the Production of Frankfurters," Meat Science, Vol. 78, No. 3, 2008, pp. 211-216. doi:10.1016/j.meatsci.2007.06.012

[4] A. Serrano, J. Librelotto, S. Cofrades, F. J. Sanchez-Muniz and F. Jiménez-Colmenero, "Comparison and Physicochemical Characteristics of Restructured Beef Steaks Containing Walnuts as Affected by Cooking Method," Meat Science, Vol. 77, No. 3, 2007, pp. 304-313. doi:10.1016/j.meatsci.2007.03.017

[5] J. D. Wood, R. I. Richardson, G. R. Nute, A. V. Fisher, M. M. Campo, E. Kasapidou, P. R. Sheard and S. M. Enser, "Effects of Fatty Acids on Meat Quality: A Review," Meat Science, Vol. 66, No. 1, 2003, pp. 21-32. doi:10.1016/S0309-1740(03)00022-6

[6] P. W. Siri-Tarino, Q. Sun, F. B. Hu and R. M. Kraurs, "Saturated Fat, Carbohydrate and Cardiovascular Disease," American Journal of Clinical Nutrition, Vol. 91, No. 3, 2010, pp. 502-509.

doi:10.3945/ajen.2008.26285

[7] E. Hughes, S. Cofrades and D. J. Troy, "Effects of Fat Level, Oat Fiber and Carragenan on Frankfurters Formulated with 5\%,12\% and 30\% Fat," Meat Science, Vol. 45, No. 3, 1997, pp. 273-281. doi:10.1016/S0309-1740(96)00109-X

[8] Z. Pietrasik and Z. Duda, "Effects of Fat Content and Soy Protein/Carragenan Mix on the Quality Characteristics of Comminuted, Scalded Sausage," Meat Science, Vol. 56, No. 2, 2000, pp. 181-188. doi:10.1016/S0309-1740(00)00038-3

[9] S. S. Yoo, S. H. Kook, S. Y. Park, J. H. Shim and K. B. Clin, "Physicochemical Characteristics, Textural Properties and Volatile Compounds in Comminuted Sausage as Affected by Various Fat Levels and Fat Replacers," International Journal of Food Science and Technology, Vol. 42, No. 9, 2007, pp. 1114-1122. doi:10.1111/j.1365-2621.2006.01402.x

[10] J. Giese, "Fats, Oils and Fat Replacers," Food Technology, Vol. 50, No. 4, 1996, pp. 78-83.

[11] E. Mendoza, M. L. Garcia, C. Caras and M. D. Selgas, "Inulin as Fat Substitute in Low Fat, Dry Fermented Sausages," Meat Science, Vol. 57, No. 4, 2001, pp. 387-393. doi:10.1016/S0309-1740(00)00116-9

[12] Y. S. Choi, J. H. Choi, D. J. Han, H. Y. Kim, M. A. Lee, J. Y. Jeong, H. J. Chung and C. J. Kim, "Effects of Replacing Pork Fat with Vegetable Oils and Rice Bran Fiber on the Quality of Reduced-Fat Frankfurters," Meat Science, Vol. 84, No. 3, 2010, pp. 557-563. doi:10.1016/i.meatsci.2009.10.012
[13] Z. Pietrasik and J. A. M. Janz, "Utilization of Pea Flour, Starch-Rich and Fiber-Rich Fractions in Low Fat Bologna," Food Research International, Vol. 43, No. 2, 2010, pp. 602-608. doi:10.1016/i.foodres.2009.07.017

[14] W. G. T. Sanjeewa, J. P. D. Wanasundara, Z. Pietrasik and P. J. Shand, "Characterization of Chickpea (Cicer arietinum L.) Flours and Application in Low-Fat Pork Bologna as a Model System," Food Research International, Vol. 43, No. 2, 2010, pp. 617-626. doi:10.1016/j.foodres.2009.07.024

[15] J. G. Bloukas, E. D. Paneras and G. C. Fournitzis, "Effect of Replacing Pork Backfat with Olive Oil on Processing and Quality Characteristics of Fermented Sausages," Meat Science, Vol. 45, No. 2, 1997, pp. 133-144. doi:10.1016/S0309-1740(96)00113-1

[16] F. Jiménez-Colmenero, "Healthier Lipid Formulation Approaches in Meat-Based Functional Foods: Technological Options for Replacement of Meat Fats by Non-meat Fats," Trends in Food Science \& Technology, Vol. 18, No. 11, 2007, pp. 567-578.

doi:10.1016/j.tifs.2007.05.006

[17] M. A. Lurueña-Martinez, A. M. Vivar-Quintana and I. Revilla, "Effect of Locust Been/Xanthan Gum Addition and Replacement of Pork Fat with Olive Oil on the Quality Characteristics of Low-Fat Frankfurters," Meat Science, Vol. 68, No. 3, 2004, pp. 383-389. doi:10.1016/j.meatsci.2004.04.005

[18] M. Servili, S. Espoto, R. Fabiani, S. Urbani, A. Taticchi, F. Moriucci, R. Selvaggini and G. F. Montedoro, "Phenolic Compounds in Olive Oil: Antioxidant, Health and Organoleptic Activities According to Their Chemical Structure," Inflammopharmacology, Vol. 17, No. 2, 2009, pp. 78-84. doi:10.1007/s10787-008-8014-y

[19] B. V. McCleary, "Development of an Integrated Total Dietary Fiber Method Consistent with the Codex Alimentarius Definition," Cereal Foods World, Vol. 55, No. 1, 2010, pp. 24-28.

[20] S. Haripriya and S. Premakumari, "Effect of Wheat Bran on Diabetic Subjects," Indian Journal of Science and Technology, Vol. 3, No. 3, 2010, pp. 284-286.

[21] B. S. Redds, Y. Hirose, L. A. Cohen, B. Simi, I. Cooma and C. V. Roa, "Prevention Potential of Wheat Bran Fractions against Experimental Colon Carcinogenesis: Implications for Human Colon Cancer Prevention," Cancer Research, Vol. 60, No. 17, 2000, pp. 4792-4797.

[22] A. H. Shenoy and J. Prakash, "Wheat Bran (Triticum aestivum): Composition, Functionality and Incorporation in Unleavened Bread," Journal of Food Quality, Vol. 25, No. 3, 2002, pp. 197-211. doi:10.1111/j.1745-4557.2002.tb01019.x

[23] M. Wargovich and B. Levin, "Grist for the Mil: Role of Cereal Fiber and Cacium in Prevention of Colon Cancer," Journal of the National Cancer Institute, Vol. 88, No. 2, 1996, pp. 67-69. doi:10.1093/inci/88.2.67

[24] F. Esposito, G. Arlotti, A. M. Bonifati, A. Napolitano, D. Vitale and V. Fogliano, "Antioxidant Activity and Dietary 
Fiber in Durum Wheat Bran by-Products," Food Research International, Vol. 38, No. 10, 2005, pp. 1167-1173. doi:10.1016/j.foodres.2005.05.002

[25] M. Vaher, K. Matso, T. Levandi, K. Helmja and M. Kaljurand, "Phenolic Compounds and the Antioxidant Activity of the Bran, Flour and Whole Grain of different Wheat Varieties," Procedia Chemistry, Vol. 2, No. 1, 2010, pp. 76-82. doi:10.1016/j.proche.2009.12.013

[26] D. U. Ahn, E. J. Lee and A. Mendonca, "Meat Decontamination by Irradiation," In: L. M. L. Nollet and F. Toldrá, Eds., Advanced Technologies for Meat Processing, CRC Press, Boca Raton, 2006, pp. 155-191.

[27] R. A. Trindade, J. Mancini-Filho and A. L. C. H. Villavicencio, "Nature Antioxidants Protecting Irradiated Beef Burger from Lipid Oxidation," LWT-Food Science and Technology, Vol. 43, No. 1, 2010, pp. 98-104. doi:10.1016/j.lwt.2009.06.013

[28] USDA-FDA, 21 CFR 197 Code of Federal Regulations, "21 Food and Drugs," Chapter 1, Food and Drug Administration, Department of Health and Human Services, Part 179, Irradiation in the Production, Processing and Handling of Food, Section 179.21, 179.25, 179.26, and 179.45, US Government Printing Office, Washington DC, 2003.

[29] G. Feiner, "Meat Products Handbook: Practical Science and Technology," Woodhead Publishing Limited, Sawston, 2006.

[30] Association of Official Analytical Chemists, "Official Methods of Analysis of AOAC," 16th Edition, 1995.

[31] Y. Folch, M. Lee and G. H. Sloena-Stanley, “A Simple Method for the Isolation and Purification of Total Lipids from Animal Tissues," Journal of Biological Chemistry, Vol. 226, No. 1, 1957, pp. 497-509.

[32] Anonymity, "Preparation of Methyl Esters of Long Chain Fatty Acids," Journal of American Oil Chemists' Society, Vol. 43, No. 5, 1966, p. 12.

[33] E. W. Murphy, P. E. Criner and B. C. Grey, "Comparison of Methods for Calculating Retentions of Nutrients in Cooked Foods," Journal of Agricultural and Food Chemistry, Vol. 23, No. 6, 1975, pp. 1153-1157. doi:10.1021/jf60202a021

[34] S. B. El-Magoli, S. Laroia and P. T. M. Hansen, "Flavor and Texture Characteristics of Low Fat Ground Beef Patties Formulated with Whey Protein Concentrate," Meat Science, Vol. 42, No. 2, 1996, pp. 179-193. doi:10.1016/0309-1740(95)00032-1

[35] C. Alasnier, A. Meynier, M. Viauand and C. Gandmer, "Hydrolytic and Oxidative Changes in the Lipids of Chicken Breast and Thigh Muscles during Refrigerated Storage," Journal of Food Science, Vol. 65, No. 1, 2000, pp. 9-14. doi:10.1111/j.1365-2621.2000.tb15947.x

[36] APHA, "Compendium of Methods for the Microbiological Examination of Foods," 3rd Edition, American Public Health Association, Washington DC, 1992.

[37] D. Roberts, W. Hooper and M. Greenwood, "Practical Food Microbiology: Methods for the Examination of
Food for Microorganisms of Public Health Significance," Public Health Laboratory Service, 1995.

[38] Oxoid, "The Oxoid Manual," 8th Edition, Oxoid Ltd., Hampshire, 1998.

[39] C. H. Collins, P. M. Lyne and J. M. Grange, "Collins and Lyne's Microbiological Methods," 6th Edition, Butterworths, Oxford, 1989.

[40] International Organization for Standardization (ISO), "Microbiology-General Guidance for Enumeration of Microorganisms," ISO-4833, 1978.

[41] E. Wierbicki, "Technological and Irradiation Conditions for Radappertization of Chicken Products Used in the United States Army Raltech Toxicology Study," Food Irradiation Processing, IAEA, 1985, pp. 79-99.

[42] SAS Institute Inc., "SAS/ STAT User's Guide," Statistical Analysis Institute, Cary, 1998.

[43] W. Zhang, S. Xiao, H. Samaraweera, E. J. Lee and D. U. Ahn, "Improving Functional Value of Meat Products," Meat Science, Vol. 86, No. 1, 2010, pp. 15-31. doi:10.1016/j.meatsci.2010.04.018

[44] M. A. Eastwood, "The Physiological Effect of Dietary Fiber: An Update," Annual Review of Nutrition, Vol. 12, 1992, pp. 19-35. doi:10.1146/annurev.nu.12.070192.000315

[45] W. G. Rothstein, "Dietary Fat, Coronary Heart Disease and Cancer: A Historical Review," Preventive Medicine, Vol. 43, No. 5, 2006, pp. 356-360. doi:10.1016/j.ypmed.2006.07.013

[46] A. E. Bilek and S. Turhan, "Enhancement of the Nutritional Status of Beef Patties by Adding Flaxseed Flour," Meat Science, Vol. 82, No. 4, 2009, pp. 472-477. doi:10.1016/j.meatsci.2009.03.002

[47] G. Yildiz-Turp and M. Serdaroglu, "Effect of Replacing Beef Fat with Hazelnut Oil on Quality Characteristics of Sucuk-A Turkish Fermented Sausage," Meat Science, Vol. 78, No. 4, 2008, pp. 447-454. doi:10.1016/j.meatsci.2007.07.013

[48] D. J. O'Byrne, S. F. O'keef and R. B. Shireman, "LowFat, Monounsaturated-Rich Diets Reduce Susceptibility of Low Density Lipoproteins to Peroxidation ex Vivo," Lipids, Vol. 33, No. 2, 1998, pp. 149-157. doi:10.1007/s11745-998-0190-1

[49] H. M. Badr, "Chemical Properties of Chicken Muscles and Skin as Affected by Gamma Irradiation and Refrigerated Storage," Journal of Food Technology, Vol. 3, No. 1, 2005, pp. 1-9.

[50] S. Besbes, H. Attia, C. Deroanue, S. Makni and C. Blecker, "Partial Replacement of Meat by Pea Fiber and Wheat Fiber: Effect on the Chemical Composition, Cooking Characteristics and Sensory Properties of Beef Burger," Journal of Food Quality, Vol. 31, No. 4, 2008, pp. 480-489. doi:10.1111/j.1745-4557.2008.00213.x

[51] E. Sánnchez-Zapata, C. M. Muñoz, E. Fuentes, J. Ferñandez-López, E. Sendra, E. Sayas, C. Navarro and J. A. Pérez-Alvarez, "Effect of Tiger Nut Fiber on Quality 
Characteristics of Pork Burger," Meat Science, Vol. 85, No. 1, 2010, pp. 70-76. doi:10.1016/j.meatsci.2009.12.006

[52] Y. S. Choi, J. H. Choi, D. J. Han, H. Y. Kim, M. A. Lee, H. W. Kim, J. Y. Jeong and C. J. Kim, "Characteristics of Low-Fat Meat Emulsion Systems with Pork Fat Replaced by Vegetable Oils and Rice Bran Fiber," Meat Science, Vol. 82, No. 2, 2009, pp. 266-271. doi:10.1016/i.meatsci.2009.01.019

[53] G. P. Hong, S. Lee and S. G. Min, "Effect of Substituted Level of Added Water for Fat on the Quality Characteristics of Spreadable Liver Sausage," Food Science and Biotechnology, Vol. 13, No. 4, 2004, pp. 397-402.

[54] J. C. Park, J. Y. Joeng, E. S. Lee, J. H. Choi, Y. S. Choi, L. H. Yu, H. D. Paik and C. J. Kim, "Effects of Replaced Plant Oils on the Quality Properties in Low-Fat Hamburger Patties," Korean Journal of Food Science and Technology, Vol. 37, No. 3, 2005, pp. 412-417.
[55] H. Du and H. Li, "Antioxidant Effect of Cassia Essential Oil on Deep-Fried Beef during the Frying Process," Meat Science, Vol. 78, No. 4, 2008, pp. 461-468. doi:10.1016/j.meatsci.2007.07.015

[56] D. G. Lim, K. H. Seol, H. J. Jeon, C. Jo and M. Lee, “Application of Electron-Beem Irradiation Combined with Antioxidants for Fermented Sausage and Its Quality Characteristic," Radiation Physics and Chemistry, Vol. 77, No. 6, 2008, pp. 818-824 doi:10.1016/i.radphyschem.2008.02.004

[57] H. M. Badr, "Use of Irradiation to Control Foodborne Pathogens and Extend the Refrigerated Market Life of Rabbit Meat," Meat Science, Vol. 67, No. 4, 2004, pp. 541-548. doi:10.1016/j.meatsci.2003.11.018

[58] H. M. Badr, "Elimination of Escherichia coli O157: H7 and Listeria monocytogenes from Raw Beef Sausage by Gamma Irradiation," Molecular Nutrition and Food Research, Vol. 49, No. 4, 2005, pp. 343-349. 